\title{
The Ethical Dimension of Public Relations in Europe: Digital Channels, Moral Challenges, Resources, and Training
}

\author{
Jens Hagelstein \\ Institute of Communication and Media Studies \\ Leipzig University, Germany \\ Corresponding author \\ E-mail address: jens.hagelstein@uni-leipzig.de \\ Postal address: Nikolaistrasse 27-29, 04109 Leipzig, Germany \\ ORCID iD: 0000-0002-6057-6699 \\ Sabine Einwiller \\ Department of Communication, Faculty of Social Sciences \\ University of Vienna, Austria \\ E-mail address: sabine.einwiller@univie.ac.at \\ ORCID iD: 0000-0002-3898-846X \\ Ansgar Zerfass \\ Institute of Communication and Media Studies \\ Leipzig University, Germany \\ \& \\ Department of Communication and Culture \\ BI Norwegian Business School, Oslo, Norway \\ E-mail address: zerfass@uni-leipzig.de \\ ORCID iD: 0000-0002-5539-4663
}

\section{Citation (APA)}

Hagelstein, J., Einwiller, S., \& Zerfass, A. (2021). The ethical dimension of public relations in Europe: Digital channels, moral challenges, resources, and training. Public Relations Review, 47, 102063. https://doi.org/10.1016/j.pubrev.2021.102063

\section{Acknowlegdments}

The authors declare no potential conflicts of interest with respect to the research, authorship, and/or publication of this article. The authors disclose receipt of financial support for the research reported in this article: The research was supported by the European Association of Communication Directors (EACD), Cision Insights, Fink \& Fuchs, Nordic Alliance for Communication \& Management (NORA), Oslo, and Centro per la Comunicazione Strategica (CECOMS), Milan. 


\begin{abstract}
Digital communication tools and practices improve the spread and impact of organisational messages. Quite often, however, they also pose moral problems. This article examines how often public relations practitioners encounter moral issues in their day-to-day work, how they assess digital communication tools and practices in terms of ethics, and the resources on which they rely to tackle moral challenges. Four research questions were addressed in an online survey among 2,324 practitioners who work in PR departments of organisations or in PR agencies across Europe. Results show that PR practitioners face more moral challenges in their daily work than they have faced in the past. Regarding digital communication tools and practices, they report moral concerns especially related to using bots, exploiting personal data for big-data analyses, paying social media influencers, and using sponsored content. Personal values and beliefs are the most important resource for dealing with moral issues - whether because only a minority of practitioners has participated in any formal ethics training within the past three years, or because existing ethical guidelines are outdated. Results call for the development of ethical guidelines that can provide explicit advice in the area of digital communication. Furthermore, structured training programs and ethics courses in graduate programs are needed to enhance practitioners' ethical knowledge.
\end{abstract}

Keywords: Ethics, moral challenges, digital communication, social media, public relations, survey 


\section{Introduction}

The ongoing digital transformation continuously introduces new technologies that fundamentally impact both our private and public communication. In the last few years, we have witnessed the rise of social network sites and public wikis, big-data analytics and profiling algorithms, and social bots and hybrid content, just to name a few. Public relations departments in organisations and public relations agencies have started to adopt or harness these technologies in their daily work. The newly emerging communication tools and practices help them to improve the reach and impact of organisational content.

Despite the potential advantages offered by new digital avenues, public relations scholars have also emphasized the ethical dimension of new communication tools and practices, and especially their moral challenges. Phillips and Young (2009) and Jensen (2011) were among the first to claim that digitalisation and the spread of social media do not only magnify existing moral issues, but also generate new conflicts. Likewise, Bachmann (2019) argued that the exploitation of digital technologies in public relations does not foster mutually beneficial relationships among all publics but rather 'breeds moral indifference and moral blindness' in attempts to win over publics (pp. 327-328).

Little is known, however, about how the situation is assessed by PR and communication management professionals themselves-those in charge of 'the steering of all communications in the context of the organization' (Brønn, 2014, p. 753). Do they face moral challenges in their daily work more often than before? Do they raise moral concerns about the digital communication tools and practices mentioned above? How do they deal with moral problems? As Coombs and Holladay (2007) have pointed out, their notion of right and wrong and their actions greatly determine the ethical standards of communication practice in the digital sphere.

So far, only a few studies have addressed the attitudes of public relations practitioners towards the morally appropriate use of digital communication tools and practices. Toledano and Wolland (2011) and Waters (2014) conducted qualitative studies about the use of social media in New Zealand and the United States. Building on the qualitative findings that highlight an intensification of moral challenges in social media and particularly around organisational transparency (Toledano \& Wolland, 2011), Toledano and Avidar (2016) developed a quantitative survey that they tested in Israel and New Zealand. This study was later replicated by Sebastião et al. (2017) in Brazil and Portugal. The findings by Toledano and Avidar (2016) revealed a lack of knowledge or care mainly around issues of transparency and truthfulness, like not disclosing the sponsor of a comment on social media, using fake identities in comments, and paying or rewarding bloggers for delivering a specific message. Similarly, Sebastião et al. (2017) reported that 'total transparency is not vehemently defended in both countries [Brazil and Portugal]' (p. 545). Both quantitative studies, however, were confined to the usage of social media communication. Conversely, Schauster and Neill (2017) interviewed advertising and PR professionals in the US on their moral concerns on native advertising, paid media, consumer privacy, and ad fraud. Finally, Wiesenberg and colleagues report on two quantitative surveys on big data and bots among European communication professionals: Only $14 \%$ of survey participants mentioned moral or legal concerns when asked for the three most relevant issues when working with big data in communications (Wiesenberg et al., 2017), but almost three quarters stated that social bots present moral challenges for them (Wiesenberg \& Tench, 2020).

The current research extends the knowledge derived from previous studies in important ways. First, it provides a comparison between the perceived frequency of moral 
challenges in 2012 and 2020, thereby offering an opportunity to show development over time. It furthermore provides a comprehensive overview of the perceived moral challenges that several important digital communication tools and practices pose for communication professionals. However, recent studies have especially lacked any insight into the resources on which PR professionals rely when tackling moral issues. The perceptions of these challenges and how they are dealt with are captured from a broad sample of 2,324 public relations practitioners across Europe. The size and diversity of the sample allows us to draw descriptive and inferential comparisons not just between individual characteristics (age and hierarchical position), but also with respect to organisational aspects (type of organisation) and socio-political factors (level of corruption in the country). Finally, the paper discusses theoretical implications of the empirical findings and offers suggestions on how to establish and secure ethical standards in the profession, thereby contributing to theory and practice in the field of PR ethics.

\section{Literature review}

\subsection{Ethics and moral challenges in public relations}

In the discipline of public relations, 'ethics includes values such as honesty, openness, loyalty, fair-mindedness, respect, integrity, and forthright communication' (Bowen, 2007, p. 1). Ethics are complementary to legal regulations; according to Cunningham (1999), they are 'concerned with questions of what ought to be done, not just with what legally must be done' (p. 500). We define morals as principles concerning human action and behaviour, whereas ethics, on the other hand, are comprised of descriptive or prescriptive reflections on morality, e.g., in form of scientific publications or professional codes (Place, 2019).

Communication professionals, therefore, may encounter moral challenges in their daily work and solve them by referring to ethical guidelines.

These challenges for practical moral behaviour arise when PR practitioners struggle to live up to the values mentioned above. By means of communication, organisations try to influence the knowledge, attitudes, and/or behaviour of those individuals or groups that contribute to their wealth-creating capacity or activities, also known as their stakeholders (Post et al., 2002). These stakeholders, however, may have interests that stand in conflict with those of the organisation to which the practitioner is to be loyal. For practitioners who communicate with the organisation's stakeholders on behalf of their employer or client, moral challenges may arise at various points in this web of relationships. For example, while consumers want to know when an organisation tries to persuade them to think or act in a certain way, the organisation may disguise its promotional content, such as with an editorial article, because this could enhance its persuasiveness. Or, while consumers value their privacy and want their personal data protected, the organisation's interest is to boost its profit by leveraging personal data for microtargeting purposes.

The European Communication Monitor (ECM) 2012, a large-scale survey among communication professionals in Europe, revealed that six out of every 10 of the roughly 2,000 participants had experienced at least one moral challenge in the previous year, and $35 \%$ of all respondents even experienced several such challenges (Zerfass et al., 2012). The results of the ECM 2012 also indicate that moral challenges are increasing. More than half of the respondents said that they face more challenges presently as compared to five years ago. Asked for possible causes for this increase, around three-quarters agreed that social media communication brings about new moral challenges. Consequently, Bowen (2013) 
stressed that the rapidly changing digital communication environment 'only heighten[s] the ethical imperative for accuracy, honesty, and full disclosure' (p. 131).

As digitalisation is continuously bringing forth new and more advanced possibilities for communicating with audiences online, moral challenges for practitioners may further increase. Thus, the following research question arises:

RQ1: What is the frequency of moral challenges that PR practitioners are currently experiencing in their day-to-day work, and has the rate increased in recent years?

\subsection{Digital tools and practices posing moral challenges}

The use of social media and other forms of digital communication has continually increased in public relations practice (Wright \& Hinson, 2017). Likewise, scholarly interest in social and 'new' media has grown steadily (Duhé, 2015; Verčič et al., 2015). The focus in academic research has almost exclusively been on using these digital media as 'tools' (Verčič et al., 2015, p. 142), while 'new media risk, whether legal, ethical, or otherwise, is . . under populated in public relations journals yet increasingly important and complex in practice' (Duhé, 2015, p. 162). In her review of communication technology research in six journals primarily dedicated to public relations, Duhé (2015) identified only four articles out of 321 that raised moral concerns. This lack of research on moral issues is problematic, because digital technologies and specifically social media can also pose risks and damage the social relation between an organisation and its stakeholders (Valentini, 2015). This raises the question of the extent to which communication professionals are conscious of the critical effects and moral challenges digital communication practices may engender. The focus in this research is on digital communication activities that are commonplace in communication practice but have been critically discussed with regards to ethics. These digital tools and practices are outlined in the following.

\subsubsection{Sponsored content}

Transparency is a major issue discussed with regards to the practice of sponsored content (Ikonen et al., 2017). In sponsored content, where promotional messages by a brand or company are integrated into journalistic media outlets or social media in order to achieve strategic goals (Bivins, 2009), the lines between editorial content and advertising are blurred (Van Reijmersdal et al., 2005). Authors also speak of hybrid forms of content (Taiminen et al., 2015). Despite disclosure labels, media audiences often do not recognise sponsored content as promotional because it smoothly blends into the environment in which it is embedded (Wojdynski et al., 2018). Non-transparency and lack of disclosure may not simply cause relational damage with stakeholders (Sweetser, 2010). Verčič and Tkalac Verčič (2016) argued that journalism - and with it, democracy-is threatened when content produced by non-core media organisations appropriates spaces that were previously occupied by traditional media.

\subsubsection{Social media influencer communication}

Transparency is also key in social media influencer communication, which has become a major topic in strategic communication. Enke and Borchers (2019) defined 'social media influencers as third-party actors that have established a significant number of relevant relationships with a specific quality to and influence on organisational stakeholders through content production, content distribution, interaction, and personal appearance on 
the social web' (p. 267). By rewarding social media influencers for supportive communication, companies or brands can gain access to relevant audiences through the voice of someone these groups presumably trust. In fact, social media influencers have a similar intermediary function as journalists, but they lack the quality standards and especially the professional ethics of journalists (Enke \& Borchers, 2019). Transparency about the influencer's relationship with a company is not always taken seriously, which can corrupt stakeholders' decision-making processes (Lahav \& Roth-Cohen, 2016). Aside from transparency issues, influencer communication is also problematic with regards to authenticity, as influencers may endorse a product only because they are paid to do so, but not because they are really in favour of it.

\subsubsection{Corporate influencers}

The practice of cooperating with social media influencers has spurred the idea that employees may serve as corporate influencers for their organisation via their private social media accounts, and several companies have established corporate influencer programs (Brockhaus et al., 2020; Marten \& Kirchmeer, 2018). In contrast to social media influencers, corporate influencers are employees of the organisation and are thus internal actors, which should make them less impactful because of their close relationship to the client organisation (Enke \& Borchers, 2019). The moral issues of transparency and authenticity are, however, similar to those of social media influencers. Companies need to ensure that corporate influencers transparently disclose their liaison with the organisation. Moral issues of authenticity may arise when employees' opinions are not supportive of their organisation's goals and they may suppress their own viewpoints because of loyalty or fear of negative repercussions. On the other hand, audiences may mistake personal opinions for standpoints of the employer. In her 15 Ethical Guidelines for Using Social Media, Bowen (2013) claims that 'personal speech and opinion versus speech as a representative of the organization should be identified' (p. 126)-a goal that corporate influencer communication might not meet in many cases. So far, little attention has been given to potential moral problems with respect to corporate influencers (Brockhaus et al., 2020).

\subsubsection{Public wikis}

Public wikis - first of all, Wikipedia-are popular online sources that can influence the reputation of a company (DiStaso et al., 2012). Therefore, companies are advised to closely monitor entries in public wikis such as Wikipedia, but '[e]diting beyond the fixing of errors is unethical' (DiStaso \& Messner, 2010, p. 19). In fact, Wikipedia has issued a policy against editing Wikipedia when there is a conflict of interest such as working in public relations (DiStaso, 2013), and the Chartered Institute of Public Relations has called on public relations practitioners to abstain from editing Wikipedia entries (CIPR, 2019). However, in a 2013 survey among communication professionals, DiStaso (2013) revealed that $34 \%$ of participants had directly edited the Wikipedia account of their organisation or client, and another $14 \%$ had used Wikipedia's 'Talk' pages to request edits. This clearly establishes moral issues of transparency, and possibly truthfulness, with regards to this online medium.

\subsubsection{Social bots}

Moral issues with regards to truthfulness and authenticity also arise with the use of social bots in communication. Social bots are computer programs that simulate a human identity and are used for manipulative purposes by communicating like people on the Internet (Woolley \& Howard, 2016). In social media, the perceived distinction between 
humans and bots is inherently blurry (Guilbeault, 2016), and most users do not recognise bots as automatic communication controlled by algorithms, but as human.

\subsubsection{Big data}

Big data, which 'denotes huge volumes and streams of different forms of data from diverse internal and external sources and their constant processing' (Wiesenberg et al., 2017, p. 96), poses opportunities and challenges for strategic communication. While advanced data collection and data mining methods help organisations to generate better targeted and more effective strategic communications, big data also bears huge challenges with regards to its correct and respectful handling (Yang \& Kang, 2015). These challenges include potential threats for individuals' privacy and the public sphere, and thus the interests of private communication and transparent public communication have to be carefully balanced (Holtzhausen \& Zerfass, 2015). Yang and Kang (2015) lamented that '[a]lthough strategic communication professionals happily embrace the opportunities provided by big data to facilitate their campaign planning, consumer privacy has received minimal attention' (p. 90).

\subsubsection{Profiling and targeting}

Big data offers the potential to microsegment individuals, and profiling and targeting of audiences is one of its most desirable benefits (Yang \& Kang, 2015). The dissemination of tailored messages to potential or current customers, consumers, and other stakeholders is a major trend in digital communication practices (Valentini, 2015). This poses moral issues especially regarding respect for personal data privacy (Barbu, 2014). Privacy concerns arise not only from the fact that data are collected, often from unwitting individuals, but also out of the ability to construct new personal information through predictive analytics (Mai, 2016). The application of analytical techniques even allows the prediction of consumers' psychological traits and states from their digital footprints (Matz \& Netzer, 2017), which allows microtargeting based on psychological profiles. A recent Pew Research Center (Auxier et al., 2019) study showed clearly that the majority of American adults were concerned about the way their data were being used by companies (79\%), and $81 \%$ said that the potential risks they faced because of data collection by companies outweighed the benefits.

With issues of stakeholder trust in mind, it is worth investigating how communication professionals perceive the moral challenges associated with the seven digital communication tools and practices discussed above. Thus, we pose the following research question:

RQ2: Which tools and practices pose moral challenges to PR practitioners when working in the digital communication environment?

\subsection{Resources and training for tackling moral challenges}

When practitioners are confronted with moral challenges, they can draw on different resources to weigh the competing interests between their organisation or client and the stakeholders they serve. These resources can be found in the individual's values and beliefs (micro level), in ethical guidelines of the organisation (meso level), and in ethical codes of practice of professional associations (macro level) (Bentele, 2015). In public relations practice, the state of ethics depends heavily on codes of ethics held by the major 
professional associations (Bowen, 2007), and members of these associations agree to abide by their respective code(s).

However, a previous study on PR ethics in Europe showed that only a minority (29\%) of the surveyed communication professionals used a professional code of ethics to solve moral problems (Zerfass et al., 2012). Those with more experience on the job and members of a professional communication organisation did so significantly more often than their younger colleagues or non-members. A point of criticism raised by European communication professionals at that time was that typical codes of ethics provided by the PR profession are outdated. Practitioners in the United States surveyed by Bowen et al. (2006) furthermore lamented that codes of ethics are too vague to be useful or that they do not give enough specific guidance. Ultimately, it is 'an individual's personal ethics [that] will guide what they do as a practitioner' (Waters, 2014, p. 15).

An important way to strengthen the resources that help tackle moral challenges is to offer ethics trainings or classes, which can be taken during university studies or after graduation. These postgraduate trainings are generally offered by professional associations or also by practitioners' employers. The findings by Bowen et al. (2006) were quite concerning: The study revealed that the majority (70\%) of participants had little if any academic training or study of ethics. Practitioners rather relied on professional experience, meaning that those with less experience could be ill-prepared to face moral dilemmas (Bowen, 2007).

In the current study we address questions of resources and training anew and ask:

RQ3: On which resources do PR professionals rely when tackling moral issues?

\subsection{Micro, meso, and macro level factors influencing the assessment of moral challenges}

Perceptions of moral challenges and resources to tackle them may vary according to individual characteristics (micro-), organisational structures (meso-), and socio-political contexts (macro-level factors). Research indicates that compared to older business professionals, younger employees exhibit a lower standard of ethical beliefs (Paterson et al., 2001). Correspondingly, Place (2019) found that PR practitioners perceive that they progress in moral development gradually via time and experience. Aside from age, there may be an impact of leadership roles, which entail more responsibility and influence, on the assessment of moral challenges or the use of resources. With respect to the meso level, the type of organisation with which a PR practitioner is employed may influence his or her encounter with moral challenges. Practitioners in agencies may feel more pressured through the need to please their clients than those working in private or non-profit organisations (Drumwright \& Murphy, 2004). The studies by Toledano and Avidar (2016) and Sebastião et al. (2017) provide indications for influences on the macro level as New Zealanders exhibited a relatively greater level of knowledge about ethics and stronger support for ethical conduct than practitioners from other countries. The authors explained this by a stronger adherence to norms supporting human freedoms and organisational transparency in this country.

Macro-societal factors like level of public-sector corruption may also affect the perception of moral challenges in the PR profession. Corruption in different countries can be identified by the Corruption Perceptions Index (CPI), which combines 13 different corruption statistics and indicates how experts and business executives perceive public sector corruption (Transparency International, 2019).

These considerations lead to the fourth and final research question: 
RQ4: How do (a) individual factors (age, hierarchical position), (b) organisational factors (type of organisation), and (c) socio-political factors (level of corruption indicated by the $\mathrm{CPI}$ ) influence the assessment of moral challenges or reliance on resources?

\section{Methodology}

\subsection{Questionnaire instrument}

Five questions were derived from the above-mentioned literature. They were embedded in a more comprehensive online questionnaire of 16 questions addressing a range of other topics besides the research reported here. Additionally, demographic data were gathered for all participants, including their gender, age, country, academic qualification, professional experience, and the type of organisation, characteristics of the department, and hierarchical position they currently work in.

The first question replicated the measure previously used by Zerfass et al. (2012) among a similar sample in order to facilitate the longitudinal comparison of moral challenges in PR today versus eight years ago. Like Zerfass et al. (2012), we asked participants whether they had experienced moral challenges in their day-to-day work during the past 12 months; possible answers were 'No', 'Yes, once', 'Yes, several times', or 'Don't know/Don't remember'. Those respondents who chose either 'Yes, once' or 'Yes, several times' were then asked to rate the importance of different resources in tackling these issues; ethical codes of practice of professional associations (resource on the macro level), ethical guidelines of their organisation (meso level), and their personal values and beliefs (micro level) were evaluated on a five-point rating scale from 1 ('Not important') to 5 ('Very important'). We then assessed participants' concerns on the seven digital tools and practices discussed in the literature review by asking how challenging they viewed them in terms of ethics. Each of the seven items-sponsored content, paid social media influencers, corporate influencers, public wikis, social bots, big data, and targeting - was evaluated on a five-point rating scale from 1 ('Ethically not challenging at all') to 5 ('Ethically extremely challenging'). Finally, we asked participants if they had had any formal training in ethics by a professional association, their organisation, or during their studies (aligned to the internal distinction of macro/meso/micro perspective), and how long ago this training was (less than 1 year ago/1 to 3 years ago/more than 3 years ago).

The questionnaire was pretested among 58 PR professionals with different demographic and professional backgrounds. Their suggestions were taken into account, and amendments were implemented where necessary.

\subsection{Sample}

The online survey was active for five weeks during January and February 2020. E-mail invitations were sent to 10,656 PR professionals working in organisations and agencies across Europe, based on a large address database built by the authors of this paper over a decade. Practitioners were also informed about the survey through social media posts.

In total, 2,498 respondents completed the questionnaire. After excluding those who could not be identified as part of the target population (e.g., academics or professionals from outside of Europe), 2,324 fully completed responses remained for data analysis. Of 
these participants, $60.6 \%$ were female $(n=1,405)$ and $39.4 \%$ were male $(n=915)$, with an average age of 43.3 years. The vast majority held an academic degree $(95.7 \%, n=2,224)$, with $63.3 \%$ having a master's/postgraduate degree $(n=1,471)$ and $8.3 \%$ a doctorate $(n=$ 192). Senior practitioners with a long tenure in the profession were predominant in the sample: $68.6 \%(n=1,593)$ of the respondents had more than 10 years of experience in the field, and $63.8 \%$ ( $n=1,483)$ were in leading positions as either head of communication/agency CEO or unit/team leader. Two-thirds of professionals worked in PR departments of joint-stock companies $(16.9 \%, n=394)$, private companies $(22.0 \%, n=511)$, government-owned, public sector, or political organisations $(18.7 \%, n=435)$, or non-profit organisations or associations $(10.1 \%, n=234)$. The others were PR consultants working in agencies or as freelancers $(32.3 \%, n=750)$. Roughly every second respondent $(51.8 \%, n=$ $1,204)$ identified as a member of a national PR or communication association; $22.5 \%(n=$ 522 ) of those surveyed were part of an international association like the European Association of Communication Directors (EACD) and 30.9\% $(n=718)$ of respondents were neither member of a national nor international PR or communication association. Most respondents $(46.8 \%, n=1,087)$ were based in countries with a CPI above 70 , indicating a low level of corruption (Transparency International, 2019). Of the respondents, $25.7 \%(n=597)$ were from countries with a CPI between 51 and 70, and 27.4\% $(n=639)$ worked in countries with a high level of corruption, indicated by a CPI of 50 or below. ${ }^{1}$

It is noteworthy that the total population of PR practitioners in Europe is not known; so it is not possible to draw a representative sample. This also means that the share of communication leaders and the amount of practitioners working in agencies in this study might differ from other studies or from the professional field. We discuss this methodological issue in the section on limitations.

\subsection{Analyses}

The collected data were analysed with the Statistical Package for the Social Sciences (SPSS). In addition to descriptive analyses, significant differences and (inter-)dependencies were revealed using either Pearson product-moment correlation or Kendall rank correlation, depending on the type of variable.

\section{Findings}

\subsection{Moral challenges in day-to-day work of $P R$ professionals}

Two thirds of the surveyed respondents (64.8\%) had faced a moral challenge in their day-to-day work within the past 12 months. Almost half of them (46.5\%) even reported two or more incidents. The latter number has increased by $11.5 \%$ compared to the results reported by Zerfass et al. (2012). The number of those without any moral issue in their daily work, on the other hand, has decreased by $8.1 \%$. In other words, practitioners report an across-the-board increase in the frequency of moral issues experienced in the space of less than a decade. ${ }^{2}$

Moral challenges posed a problem especially for professionals working in PR consultancies and agencies, with every second consultant $(50.1 \%)$ having faced several

\footnotetext{
${ }^{1} \mathrm{CPI}$ scores are not available for Andorra and Liechtenstein. Participants based in these countries were excluded from the relevant analyses.

${ }^{2} n=181$ participants (7.8\% of the total sample) ticked the 'Don't know/Don't remember' option.
} 
challenges within the past 12 months (see Table 1 ). The biggest overall increase from zero to one or more challenges between 2012 and 2020 was seen in private companies (9.2\%).

Table 1. Number of moral challenges encountered by PR professionals in day-to-day work in the past year across different types of organisations. Comparison between 2012 and 2020.

\begin{tabular}{|c|c|c|c|c|c|c|c|}
\hline & & $\begin{array}{l}\text { Joint-stock } \\
\text { companies }\end{array}$ & $\begin{array}{c}\text { Private } \\
\text { companies }\end{array}$ & $\begin{array}{c}\text { Governmental } \\
\text { organisations }\end{array}$ & $\begin{array}{c}\text { Non-profit } \\
\text { organisations }\end{array}$ & $\begin{array}{l}\text { Consultan- } \\
\text { cies \& } \\
\text { agencies }\end{array}$ & Overall \\
\hline \multirow{3}{*}{$\begin{array}{l}\text { Several } \\
\text { moral } \\
\text { challenges }\end{array}$} & 2020 & $\begin{array}{c}41.3 \% \\
(n=151)\end{array}$ & $\begin{array}{c}44.7 \% \\
(n=209)\end{array}$ & $\begin{array}{c}46.4 \% \\
(n=185)\end{array}$ & $\begin{array}{c}48.4 \% \\
(n=106)\end{array}$ & $\begin{array}{c}50.1 \% \\
(n=346)\end{array}$ & $\begin{array}{c}46.5 \% \\
(n=997)\end{array}$ \\
\hline & 2012 & $\begin{array}{c}30.3 \% \\
(n=188)\end{array}$ & $\begin{array}{c}33.9 \% \\
(n=145)\end{array}$ & $\begin{array}{c}35.2 \% \\
(n=123)\end{array}$ & $\begin{array}{c}40.1 \% \\
(n=109)\end{array}$ & $\begin{array}{c}39.3 \% \\
(n=184)\end{array}$ & $\begin{array}{c}35.0 \% \\
(n=749)\end{array}$ \\
\hline & $\Delta$ in $\%$ & $+11.0 \%$ & $+10.8 \%$ & $+11.2 \%$ & $+8.3 \%$ & $+10.8 \%$ & $+11.5 \%$ \\
\hline \multirow{3}{*}{$\begin{array}{l}\text { One } \\
\text { moral } \\
\text { challenge }\end{array}$} & 2020 & $\begin{array}{c}18.9 \% \\
(n=69)\end{array}$ & $\begin{array}{c}20.3 \% \\
(n=95)\end{array}$ & $\begin{array}{c}15.3 \% \\
(n=61)\end{array}$ & $\begin{array}{c}16.4 \% \\
(n=36)\end{array}$ & $\begin{array}{c}19.1 \% \\
(n=132)\end{array}$ & $\begin{array}{c}18.3 \% \\
(n=393)\end{array}$ \\
\hline & 2012 & $\begin{array}{c}22.7 \% \\
(n=141)\end{array}$ & $\begin{array}{c}22.0 \% \\
(n=94)\end{array}$ & $\begin{array}{c}19.5 \% \\
(n=68)\end{array}$ & $\begin{array}{c}20.2 \% \\
(n=55)\end{array}$ & $\begin{array}{c}22.6 \% \\
(n=106)\end{array}$ & $\begin{array}{c}21.7 \% \\
(n=464)\end{array}$ \\
\hline & $\Delta$ in $\%$ & $-3.8 \%$ & $-1.7 \%$ & $-4.2 \%$ & $-3.8 \%$ & $-3.5 \%$ & $-3.4 \%$ \\
\hline \multirow{3}{*}{$\begin{array}{l}\text { No } \\
\text { moral } \\
\text { challenges }\end{array}$} & 2020 & $\begin{array}{c}39.9 \% \\
(n=146)\end{array}$ & $\begin{array}{c}35.0 \% \\
(n=164)\end{array}$ & $\begin{array}{c}38.3 \% \\
(n=153)\end{array}$ & $\begin{array}{c}35.2 \% \\
(n=77)\end{array}$ & $\begin{array}{c}30.8 \% \\
(n=213)\end{array}$ & $\begin{array}{c}35.1 \% \\
(n=753)\end{array}$ \\
\hline & 2012 & $\begin{array}{c}46.9 \% \\
(n=291)\end{array}$ & $\begin{array}{c}44.2 \% \\
(n=189)\end{array}$ & $\begin{array}{c}45.3 \% \\
(n=158)\end{array}$ & $\begin{array}{c}39.7 \% \\
(n=108)\end{array}$ & $\begin{array}{c}38.0 \% \\
(n=178)\end{array}$ & $\begin{array}{c}43.2 \% \\
(n=924)\end{array}$ \\
\hline & $\Delta$ in $\%$ & $-7.0 \%$ & $-9.2 \%$ & $-7.0 \%$ & $-4.5 \%$ & $-7.2 \%$ & $-8.1 \%$ \\
\hline
\end{tabular}

Note. $n=2,143$ PR professionals in Europe (2020) and $n=2,137$ PR professionals in Europe (2012). Q (2020): Like anyone else, communication professionals sometimes face situations where particular activities might be legally acceptable, but challenging from a moral point of view. In your day-to-day work during the past 12 months, have you experienced ethical challenges? No/Yes, once/Yes, several times/Don't know or don't remember. Q (2012): Like anyone else, communication professionals sometimes face situations where particular activities might be legally acceptable, but challenging from a moral point of view. In your daily work, did you experience ethical challenges within the last 12 months? No/Yes, once/Yes, several times/Don't know.

Furthermore, political circumstances were reflected in public relations practice: PR practitioners who worked in countries suffering from high levels of corruption were significantly more often confronted with moral challenges in their daily work. On the other hand, communication professionals in mostly corruption-free countries reported fewer moral issues (see Table 2). 
Table 2. Number of moral challenges encountered by PR professionals in day-to-day work in the past year across countries with different CPI ranges.

\begin{tabular}{|c|c|c|c|c|}
\hline & $\begin{array}{c}\mathrm{CPI} \leq 50 \\
\text { (high level } \\
\text { of corruption) }\end{array}$ & $\begin{array}{c}\text { CPI 51-70 } \\
\text { (medium level } \\
\text { of corruption) }\end{array}$ & $\begin{array}{c}\mathrm{CPI} \geq 71 \\
\text { (low level } \\
\text { of corruption) }\end{array}$ & Overall \\
\hline $\begin{array}{l}\text { Several } \\
\text { moral } \\
\text { challenges }\end{array}$ & $\begin{array}{c}53.9 \% \\
(n=319)\end{array}$ & $\begin{array}{c}49.2 \% \\
(n=270)\end{array}$ & $\begin{array}{c}40.8 \% \\
(n=408)\end{array}$ & $\begin{array}{c}46.6 \% \\
(n=997)\end{array}$ \\
\hline $\begin{array}{l}\text { One } \\
\text { moral } \\
\text { challenge }\end{array}$ & $\begin{array}{c}16.9 \% \\
(n=100)\end{array}$ & $\begin{array}{c}19.7 \% \\
(n=108)\end{array}$ & $\begin{array}{c}18.4 \% \\
(n=184)\end{array}$ & $\begin{array}{c}18.3 \% \\
(n=392)\end{array}$ \\
\hline $\begin{array}{l}\text { No } \\
\text { moral } \\
\text { challenges }\end{array}$ & $\begin{array}{c}29.2 \% \\
(n=173)\end{array}$ & $\begin{array}{c}31.1 \% \\
(n=171)\end{array}$ & $\begin{array}{c}40.8 \% \\
(n=408)\end{array}$ & $\begin{array}{c}35.1 \% \\
(n=752)\end{array}$ \\
\hline
\end{tabular}

Note. $n=2,141$ PR professionals in Europe (2020). Q: Like anyone else, communication professionals sometimes face situations where particular activities might be legally acceptable, but challenging from a moral point of view. In your day-to-day work during the past 12 months, have you experienced ethical challenges? No/Yes, once/Yes, several times/Don't know or don't remember. Highly significant at the $p \leq 0.01$ level based on Pearson's Chi-squared test.

\subsection{Assessment of digital communication tools and practices in terms of ethics}

Our next set of questions asked public relations practitioners to denote whether the seven controversial tactics discussed above raise concerns for their profession. For these questions, a response of 4 or 5 on the five-point scale corresponded to a belief that the practice was very challenging or extremely challenging in terms of ethics. Notable, two out of every three PR professionals (67.6\%, scale points 4 and 5 ) found the use of bots to generate feedback and followers on social media extremely challenging or very ethically challenging $(M=3.89, S D=1.21, n=2,121)$. A majority of respondents identified moral dilemmas associated with the exploitation of audiences' personal data by applying big-data analyses (58.1\%; $M=3.61, \mathrm{SD}=1.23, n=2,198)$, with paid social media influencer communication (55.4\%; $M=3.51, \mathrm{SD}=1.27, n=2,213$ ), and with the usage of normallooking sponsored content ( $54.0 \% ; M=3.47, \mathrm{SD}=1.26, n=2,244)$. Of the surveyed professionals, $40.8 \%$ were heavily concerned about motivating employees to spread organisational messages on their private social media accounts $(M=3.06, \mathrm{SD}=1.34, n=$ 2,280 ). Profiling and targeting audiences based on age, gender, ethnicity, job, or interests ( $M$ $=2.75, \mathrm{SD}=1.31, n=2,266)$, and editing entries about the organisation on public wikis $(M=$ $2.70, \mathrm{SD}=1.25, n=2,128)$ were assessed by less than a third of the participants as extremely or very challenging (30.2\% and $27.2 \%$, respectively). Despite these differences in percentages, however, it is worth mentioning that mean values for every item are above the centre of the scale (2.5).

For some of the items, significant correlations between respondent age and their strength of moral concerns were revealed (see Table 3). Generally speaking, the older the professionals were, the more critically they assessed the described communication tools and practices in terms of ethics. 
Table 3. Moral concerns on digital communication tools across generations.

\begin{tabular}{|c|c|c|c|c|c|c|}
\hline & $\begin{array}{c}29 \text { or } \\
\text { younger }\end{array}$ & $30-39$ & $40-49$ & 50-59 & $\begin{array}{l}60 \text { or } \\
\text { older }\end{array}$ & Overall \\
\hline $\begin{array}{l}\text { Using bots to generate feedback } \\
\text { and followers on social media* }\end{array}$ & $\begin{array}{c}3.81 \\
(1.26)\end{array}$ & $\begin{array}{c}3.79 \\
(1.23)\end{array}$ & $\begin{array}{c}3.90 \\
(1.20)\end{array}$ & $\begin{array}{c}4.03 \\
(1.14)\end{array}$ & $\begin{array}{c}3.82 \\
(1.32)\end{array}$ & $\begin{array}{c}3.89 \\
(1.21)\end{array}$ \\
\hline $\begin{array}{l}\text { Exploiting audiences' personal data } \\
\text { by applying big-data analyses } * *\end{array}$ & $\begin{array}{l}3.57 \\
(1.17)\end{array}$ & $\begin{array}{l}3.60 \\
(1.25)\end{array}$ & $\begin{array}{l}3.56 \\
(1.21)\end{array}$ & $\begin{array}{l}3.69 \\
(1.25)\end{array}$ & $\begin{array}{c}3.72 \\
(1.27)\end{array}$ & $\begin{array}{c}3.61 \\
(1.23)\end{array}$ \\
\hline $\begin{array}{l}\text { Paying social media influencers } \\
\text { to communicate favourably } * *\end{array}$ & $\begin{array}{l}3.29 \\
(1.28)\end{array}$ & $\begin{array}{l}3.29 \\
(1.27)\end{array}$ & $\begin{array}{l}3.50 \\
(1.20)\end{array}$ & $\begin{array}{l}3.75 \\
(1.30)\end{array}$ & $\begin{array}{l}3.90 \\
(1.31)\end{array}$ & $\begin{array}{c}3.51 \\
(1.27)\end{array}$ \\
\hline $\begin{array}{l}\text { Using normal-looking sponsored } \\
\text { social media posts and sponsored } \\
\text { articles on news websites }\end{array}$ & $\begin{array}{c}3.32 \\
(1.21)\end{array}$ & $\begin{array}{l}3.29 \\
(1.25)\end{array}$ & $\begin{array}{c}3.49 \\
(1.24)\end{array}$ & $\begin{array}{c}3.59 \\
(1.30)\end{array}$ & $\begin{array}{c}3.93 \\
(1.23)\end{array}$ & $\begin{array}{c}3.47 \\
(1.26)\end{array}$ \\
\hline $\begin{array}{l}\text { Motivating employees to spread } \\
\text { organisational messages on their } \\
\text { private social media accounts }\end{array}$ & $\begin{array}{l}3.24 \\
(1.34)\end{array}$ & $\begin{array}{c}3.11 \\
(1.36)\end{array}$ & $\begin{array}{c}2.90 \\
(1.32)\end{array}$ & $\begin{array}{l}3.12 \\
(1.32)\end{array}$ & $\begin{array}{c}3.21 \\
(1.39)\end{array}$ & $\begin{array}{l}3.06 \\
(1.34)\end{array}$ \\
\hline $\begin{array}{l}\text { Profiling and targeting audiences } \\
\text { based on their age, gender, } \\
\text { ethnicity, job, or interests } * *\end{array}$ & $\begin{array}{l}2.80 \\
(1.32)\end{array}$ & $\begin{array}{c}2.64 \\
(1.32)\end{array}$ & $\begin{array}{c}2.60 \\
(1.26)\end{array}$ & $\begin{array}{c}2.98 \\
(1.33)\end{array}$ & $\begin{array}{l}3.06 \\
(1.27)\end{array}$ & $\begin{array}{l}2.75 \\
(1.31)\end{array}$ \\
\hline $\begin{array}{l}\text { Editing entries about the } \\
\text { organisation on public wikis }\end{array}$ & $\begin{array}{r}2.81 \\
(1.23) \\
\end{array}$ & $\begin{array}{c}2.73 \\
(1.26) \\
\end{array}$ & $\begin{array}{r}2.63 \\
(1.23) \\
\end{array}$ & $\begin{array}{c}2.67 \\
(1.25) \\
\end{array}$ & $\begin{array}{c}2.84 \\
(1.32) \\
\end{array}$ & $\begin{array}{r}2.70 \\
(1.25) \\
\end{array}$ \\
\hline
\end{tabular}

Note. Standard deviations appear in parentheses below the means. $n \geq 2,121$ PR professionals in Europe. Q: Strategic communication and public relations are constantly evolving and introducing new ways of communicating with stakeholders. How challenging are the following practices in your opinion in terms of ethics? Five-point rating scale ranging from $1=$ 'Ethically not challenging at all' to $5=$ 'Ethically extremely challenging'. * Significant at the $p \leq 0.05$ level based on Pearson correlation. $* *$ Highly significant at the $p \leq 0.01$ level based on Pearson correlation.

\subsection{Resources for tackling moral issues}

Despite the intensity with which respondents tended to flag the moral problems described above, the PR professionals we surveyed confirmed that the most relevant resource when dealing with moral issues was their personal values and beliefs. Of the respondents, $86.1 \%$ found them important or very important when encountering moral problems $(M=4.42, S D=0.92)$. This category was followed by ethical guidelines provided by organisations, which were rated as important by $76.5 \%$ of the respondents $(M=4.12, \mathrm{SD}=$ 1.05). Ethical codes of practice of professional associations were least relevant, with only half of the surveyed practitioners (57.5\%) finding them important $(M=3.53, S D=1.31)$.

A significant difference on this assessment is seen across the various hierarchical levels of the respondents (see Table 4). Communication leaders relied even more on personal values and beliefs than did their peers. The perceived importance of this microlevel resource mirrors the organisational hierarchy. 
Table 4. Resources used when dealing with moral issues across hierarchical levels within organisations.

\begin{tabular}{|c|c|c|c|c|}
\hline & $\begin{array}{c}\text { Head of } \\
\text { communication } \\
\text { department/agency } \\
\text { CEO }\end{array}$ & $\begin{array}{l}\text { Unit } \\
\text { leader/team } \\
\text { leader }\end{array}$ & $\begin{array}{c}\text { Team } \\
\text { member/consultant }\end{array}$ & Overall \\
\hline $\begin{array}{l}\text { Ethical codes of practice of } \\
\text { professional associations (macro } \\
\text { level) }\end{array}$ & $\begin{array}{c}3.50 \\
(1.33)\end{array}$ & $\begin{array}{c}3.55 \\
(1.33)\end{array}$ & $\begin{array}{c}3.54 \\
(1.27)\end{array}$ & $\begin{array}{c}3.53 \\
(1.31)\end{array}$ \\
\hline $\begin{array}{l}\text { Ethical guidelines of } \\
\text { the organisation (meso level) }\end{array}$ & $\begin{array}{c}4.15 \\
(1.04)\end{array}$ & $\begin{array}{c}4.20 \\
(0.99)\end{array}$ & $\begin{array}{c}4.00 \\
(1.09)\end{array}$ & $\begin{array}{c}4.12 \\
(1.05)\end{array}$ \\
\hline $\begin{array}{l}\text { Personal values } \\
\text { and beliefs (micro level) ** }\end{array}$ & $\begin{array}{c}4.51 \\
(0.84)\end{array}$ & $\begin{array}{c}4.41 \\
(0.97)\end{array}$ & $\begin{array}{c}4.32 \\
(0.95)\end{array}$ & $\begin{array}{c}4.42 \\
(0.92)\end{array}$ \\
\hline
\end{tabular}

Note. Standard deviations appear in parentheses below the means. $n \geq 957$ PR professionals in Europe. Q: How important were the following resources to you when dealing with ethical challenges? Five-point rating scale ranging from $1=$ 'Not important' to $5=$ 'Very important'. ${ }^{* *}$ Highly significant at the $p \leq 0.01$ level based on Kendall rank correlation.

About half of the surveyed PR professionals (53.4\%) had had some kind of ethics training during their education or professional career. ${ }^{3}$ Of the respondents, $16.8 \%$ had taken ethics classes during their studies, $13.9 \%$ had participated in ethics training within their organisation, and another $13.9 \%$ had attended courses offered by a professional association. A small portion (between $1.5 \%$ and $2.8 \%$ ) had utilised different sources to gain expertise in communication ethics (see Table 5).

Of the participants, $17.7 \%$ had had their last training within the past year and $14.7 \%$ within up to 3 years ago; $21.0 \%$ had attended their last training more than 3 years ago. Overall, $34.4 \%$ had had some kind of training in ethics either within the past 3 years or by at least two different sources, and therefore, their education in communication ethics can be considered reasonably up-to-date. In contrast, two out of three professionals in the field of public relations (65.6\%) had had insufficient or non-recent training, or in some cases, no courses in communication ethics at all.

\footnotetext{
${ }^{3} 38.0 \%$ ( $n=884$ ) of the respondents ticked the option 'No, never', and another $8.6 \%(n=200)$ were not able to report either a source or point in time of their last training in ethics.
} 
Table 5. Training in ethics. Sources and point in time.

\begin{tabular}{|c|c|c|c|c|}
\hline & $\begin{array}{l}\text { Last training } \\
\text { less than } 1 \\
\text { year ago } \\
\end{array}$ & $\begin{array}{c}\text { Last training } \\
1 \text { to } 3 \\
\text { years go }\end{array}$ & $\begin{array}{l}\text { Last training } \\
\text { more than } \\
3 \text { years ago }\end{array}$ & Total \\
\hline $\begin{array}{l}\text { Ethics training(s) by a } \\
\text { professional association only }\end{array}$ & $\begin{array}{c}4.6 \% \\
(n=106)\end{array}$ & $\begin{array}{c}4.2 \% \\
(n=98)\end{array}$ & $\begin{array}{c}5.1 \% \\
(n=119)\end{array}$ & $\begin{array}{c}13.9 \% \\
(n=323)\end{array}$ \\
\hline $\begin{array}{l}\text { Ethics training(s) by the } \\
\text { organisation only }\end{array}$ & $\begin{array}{c}7.0 \% \\
(n=163)\end{array}$ & $\begin{array}{c}4.6 \% \\
(n=106)\end{array}$ & $\begin{array}{c}2.3 \% \\
(n=54)\end{array}$ & $\begin{array}{c}13.9 \% \\
(n=323)\end{array}$ \\
\hline $\begin{array}{l}\text { Ethics class(es) } \\
\text { during studies only }\end{array}$ & $\begin{array}{c}2.3 \% \\
(n=54)\end{array}$ & $\begin{array}{c}3.0 \% \\
(n=69)\end{array}$ & $\begin{array}{c}11.5 \% \\
(n=267)\end{array}$ & $\begin{array}{c}16.8 \% \\
(n=390)\end{array}$ \\
\hline $\begin{array}{l}\text { Ethics trainings by both } \\
\text { a professional association } \\
\text { and the organisation }\end{array}$ & $\begin{array}{c}1.2 \% \\
(n=27)\end{array}$ & $\begin{array}{c}0.8 \% \\
(n=19)\end{array}$ & $\begin{array}{c}0.4 \% \\
(n=10)\end{array}$ & $\begin{array}{c}2.4 \% \\
(n=56)\end{array}$ \\
\hline $\begin{array}{l}\text { Ethics trainings by both } \\
\text { a professional association } \\
\text { and during studies }\end{array}$ & $\begin{array}{c}0.8 \% \\
(n=18)\end{array}$ & $\begin{array}{c}0.6 \% \\
(n=14)\end{array}$ & $\begin{array}{c}0.7 \% \\
(n=15)\end{array}$ & $\begin{array}{c}2.0 \% \\
(n=47)\end{array}$ \\
\hline $\begin{array}{l}\text { Ethics trainings by both } \\
\text { the organisation } \\
\text { and during studies }\end{array}$ & $\begin{array}{c}1.0 \% \\
(n=22)\end{array}$ & $\begin{array}{c}1.0 \% \\
(n=25)\end{array}$ & $\begin{array}{c}0.8 \% \\
(n=19)\end{array}$ & $\begin{array}{c}2.8 \% \\
(n=66)\end{array}$ \\
\hline $\begin{array}{l}\text { Ethics training by } \\
\text { professional association, } \\
\text { organisation, and during } \\
\text { studies }\end{array}$ & $\begin{array}{c}0.9 \% \\
(n=21)\end{array}$ & $\begin{array}{c}0.5 \% \\
(n=11)\end{array}$ & $\begin{array}{l}0.1 \% \\
(n=3)\end{array}$ & $\begin{array}{c}1.5 \% \\
(n=35)\end{array}$ \\
\hline Total & $\begin{array}{c}17.7 \% \\
(n=411)\end{array}$ & $\begin{array}{c}14.7 \% \\
(n=342)\end{array}$ & $\begin{array}{c}21.0 \% \\
(n=487)\end{array}$ & $\begin{array}{c}53.4 \% \\
(n=1240)\end{array}$ \\
\hline
\end{tabular}

Note. $N=2,324$ PR professionals in Europe. Q: Have you ever participated in trainings on communication ethics? Yes, I have participated in communication ethics training(s) by a professional association; Yes, I have participated in communication ethics training(s) by my organisation; Yes, I took a communication ethics class(es) during my studies; No, never; Don't know/don't remember. Q: When was the last time you participated in communication ethics training? Less than 1 year ago; 1 to 3 years ago; More than 3 years ago; I haven't participated in any communication ethics training so far; Don't know/don't remember.

\section{Discussion and conclusion}

The research indicates that moral challenges with which PR professionals are confronted are rising across all types of organisations. This is likely due to the proliferation of digital tools and practices that evoke moral concerns in many. Of the tools and practices addressed in the survey, the use of social bots was considered the most challenging from an ethical standpoint, particularly by older professionals. But many also perceived the exploitation of their audience's personal data, paying social media influencers, and sponsored content very critically. When navigating these ethical quandaries, personal values and beliefs are the most important and ethical codes by professional associations the least important resource for dealing with these issues, and only a minority of respondents had participated in a formal ethics training within the past three years. These findings bear several theoretical and practical implications, as discussed in the following.

\subsection{Theoretical implications}

In his seminal work on dialogue in public relations, Pearson (1989) suggested that public relations is ethical when it is oriented on dialogue. Following this line of argument, 
Kent and Taylor (2002) noted that digital channels 'come . . closest to the interpersonal ideal' of dialogue (p. 31). Indeed, many of the tools and practices discussed in the present research help organisations to initiate and foster dialogue with their audiences. But they also introduce moral pitfalls and challenge PR practitioners with new dilemmas. In line with this observation, our study shows how the number of moral issues in the day-to-day work of PR professionals in Europe has increased over recent years. Although our study addressed the micro-level of individual professionals and their personal perceptions, we also uncovered structural influences: Practitioners in agencies and regions with high levels of corruption are affected more strongly. The latter result replicates previous findings by Toledano and Avidar (2016) and Sebastião et al. (2017) on the interrelationship between PR practice and its sociopolitical environment. Notably, $40 \%$ of the total sample reported no moral difficulties at all or did not recall any such issues. This can be interpreted in two ways. Either they were indeed not confronted with any moral challenges, or they suffer from 'moral blindness' (Bachmann, 2019, p. 326) and were not even able to identify or remember the incidents as such. This latter interpretation coincides with Bachmann's (2019) concern that 'algorithmic public relations ... bypasses moral questions' (p. 328).

Regarding specific digital practices, previous surveys among PR practitioners in Europe have indicated reservations in the adoption of bots and big data. Only every fifth PR professional works in a department or agency that has already implemented big data activities (Wiesenberg et al., 2017), while social bots are currently used by not more than a small portion (4\%) of the surveyed practitioners (Wiesenberg \& Tench, 2020). These observations may be attributed to a lack of practical uses in daily work, or to insufficient technology and data competencies of PR professionals as revealed by Wiesenberg et al. (2017) and Zerfass et al. (2020). Our study implies that moral concerns might also play a decisive role in restricting practitioners: Bot usage and big data exploitation were ranked as the most problematic practices in digital communication. Partnerships with social media influencers and paid media, on the other hand, are already broadly used (Borchers, 2019; Zerfass et al., 2016), although practitioners' moral concerns related to this practice are nearly as high-a puzzling result at first sight. However, it has been shown that paid media activities in the form of sponsored content and influencer relations are seldom among the areas of responsibility of PR practitioners, but are instead practiced by marketing and advertising professionals (Hagelstein \& Zerfass, 2020). This present survey suggests that PR practitioners stay away from these practices, at least to some extent, for moral concerns.

An alarmingly small portion of respondents is able to face the situation of increasing moral challenges with a sound education on communication ethics. Our findings point to the assumption that moral decisions are mostly gut decisions, at least in a great number of cases-either because formal guidelines and codes of practices are unknown, non-existent, or not applicable to digital channels, as revealed by Bowen et al. (2006) and Zerfass et al. (2012). We consider this situation highly problematic from a micro, meso, and macro perspective. For as Bowen (2008) suggested, PR professionals could act as counsellor to the dominant coalition in their organisation on moral issues. However, specific knowledge, skills, and expertise are needed for this (L'Etang, 2011). Practitioners without an adequate ethical education may fail to fulfil this role and suffer reputional loss among their peers and superiors. From an organisational viewpoint, morally questionable behaviour may pose threats to an organisation's 'license to operate' (Zerfass, 2008, p. 68) when such behaviour gets uncovered and scandalised by journalists or activists. Beyond that, Taylor (2010) stressed that '[p]ublic relations' role in society is to create (and re-create) the conditions that enact civil society' (p. 7). Thus, immoral digital communication practices by companies, 
governmental organisations, and non-profits may ultimately endanger communication standards in the public sphere and harm values of democracy.

\subsection{Practical implications}

Various actors are responsible to overcome this delicate situation and to endow the profession of public relations with a more solid background on communication ethics.

Professional associations need to constantly update their ethical guidelines or develop new codes from scratch to stay on par with the ever-evolving tools and practices and the increasing number of moral challenges. Ikonen et al. (2017) uncovered how existing codes of ethics in the discipline fail to address sponsored content sufficiently. In joint endeavours with academics in the fields of public relations, professional associations can develop codes of ethics that are both rooted in theory and research and practically applicable. A good example of how this can be done is the ethical code for social media influencer communications, developed by the German association for influencer marketing (Bundesverband Influencer Marketing e.V.) in cooperation with academic researchers in the field of strategic communication (Enke et al., 2019). These guidelines address moral challenges of paid social media influencer communications and provide orientation to practitioners. Another example is the "Ethics in Digital Communication" code of conduct developed by the Austrian Ethics Council on Public Relations (PR-Ethik-Rat, 2018), which is also recommended as a guideline by the International Communications Consultancy Organization (ICCO). This ethics code offers specific guidelines for practitioners with regards to several issues of digital communication ethics, including transparency and labelling of paid content, fair and respectful online communication, and responsibilities for social media communication. Offering practical tools like these may also help PR associations to attract new members: As noted in the description of our sample, a significant share of participants is still not yet a member of a national or international PR association.

Organisations can adopt these ethical guidelines and modify them to their specific needs. Advice on morally preferable actions may differ according to the purpose and strategy of the specific organisation and its stakeholders, as there cannot be a one-size-fitsall solution. Furthermore, organisations should provide regular training sessions to implement channel-specific guidelines and to enhance the general problem-solving skills of their staff for moral hazards. These sessions may-in the best interest of the organisation and its reputation-even become mandatory for communication leaders. The necessity for this is implied by our study, as heads of communication departments and agency CEOs are the ones who most strongly rely on their personal values and beliefs rather than any official guidelines when it comes to moral decisions.

$P R$ scholars also have a responsibility. National (Linke \& Kiesenbauer, 2015) and global (Austin \& Toth, 2011) studies have identified a lack of dedicated ethics courses for most undergraduate and graduate curricula in public relations. We suggest that graduate programs targeting future public relations professionals and managers should add such mandatory courses. According to educators surveyed by Austin and Toth (2011), ethics should be taught by referring to real-life examples rather than abstract theory.

\subsection{Limitations and future research}

A few limitations need to be considered when interpreting the results of this study. The first limitation regards the survey sample. As there is no registry of all PR professionals 
in Europe, and both their total number and the structure of the field are unknown, it was not possible to generate a representative sample. Yet, it can be noted that the percentage of highly qualified communication leaders with more than a decade of professional experience was high in our survey. Furthermore, the balance between in-house professionals and consultants from agencies might not reflect the distribution in real life. Therefore, generalisations to all PR practitioners in Europe need to be made with great caution. The second limitation relates to the chosen method that only allowed us to gather perceptions. Results very much depended on respondents' ability to correctly recall the moral problems they had encountered, and we cannot rule out the possibility that respondents had forgotten certain incidents. Finally, while social desirability poses a problem for almost every research endeavour in the social sciences, studies on ethics might be especially prone to it. Consequently, small differences in item wordings could have led to different tendencies in responses.

Despite these limitations, we believe that the study is able to provide valuable insights into the ethical dimension of PR and to offer clear and focused recommendations for practice. While previous studies have researched only one or two countries, or have narrowed their focus to a specific digital tool or practice, this research explored both a larger geographical area and the subject more broadly. Nevertheless, a study investigating moral challenges in PR on a global scale is still missing. This might be a worthwhile endeavour for future research. Moreover, while our research focussed on digital tools and practices, future research could extend the scope and discuss ethics in the wider context of sustainable organisations and departments. This may include aspects of diversity, inclusion, conditions of labour, or carbon neutrality. Eventually, we suggest that scholars replicate the study at hand within the next few years, using a similar instrument, in order to track the development of moral issues. Over the last eight years, PR practitioners have faced a tremendous increase in moral issues that they've experienced, and as digital innovation proliferates, we are almost certain to observe a continuing increase. 


\section{References}

Austin, L. L., \& Toth, E. L. (2011). Exploring ethics education in global public relations curricula: Analysis of international curricula descriptions and interviews with public relations educators. Public Relations Review, 37(5), 506-512.

Auxier, B., Rainie, L., Anderson, M., Perrin, A., Kumar, M., \& Turner, E. (2019, November 15). Americans and privacy: Concerned, confused and feeling lack of control over their personal information. Pew Research Center. https://www.pewresearch.org/internet/2019/11/15/americans-and-privacyconcerned-confused-and-feeling-lack-of-control-over-their-personal-information

Bachmann, P. (2019). Public relations in liquid modernity: How big data and automation cause moral blindness. Public Relations Inquiry, 8(3), 319-331.

Barbu, O. (2014). Advertising, microtargeting and social media. Procedia-Social and Behavioral Sciences, 163, 44-49.

Bentele, G. (2015). Ethik der Public Relations - Grundlagen, Probleme und Reflexion. In R. Fröhlich, P. Szyszka, \& G. Bentele (Eds.), Handbuch der Public Relations (pp. 10691087). Springer Fachmedien.

Bivins, T. (2009). Mixed media: Moral distinctions in advertising, public relations, and journalism (2nd ed.). Routledge.

Borchers, N. S. (2019). Social media influencers in strategic communication. International Journal of Strategic Communication, 13(4), 255-260.

Bowen, S. A. (2007, October 30). Ethics and public relations. Institute for Public Relations. https://instituteforpr.org/ethics-and-public-relations

Bowen, S. A. (2008) A state of neglect: public relations as 'corporate conscience' or ethics counsel. Journal of Public Relations Research, 20(3), 271-296.

Bowen, S. A. (2013). Using classic social media cases to distill ethical guidelines for digital engagement. Journal of Mass Media Ethics, 28(2), 119-133.

Bowen, S. A., Heath, R. L., Lee, J., Painter, G., Agraz, F. J., McKie, D., \& Toledano, M. (2006). The business of truth: A guide to ethical communication. International Association of Business Communicators.

Brockhaus, J., Dicke, L., Hauck, P., \& Volk, S. C. (2020). Employees as corporate ambassadors: A qualitative study exploring the perceived benefits and risks from three perspectives. In A. Tkalac Verčič, R. Tench, \& S. Einwiller (Eds.), Joy: Using strategic communication to improve well-being and organizational success (pp. 115-134). Emerald.

Brønn, P. S. (2014). Communication management. In W. Donsbach (Ed.), The international encyclopedia of communication (pp. 753-757). Wiley.

Carroll, J. (2019, January 24). Reuters article highlights ethical issues with native advertising. Columbia Journalism Review. https://www.cjr.org/watchdog/reuters-article-thaifishing-sponsored-content.php

CIPR (2019, May 30). 'Respect Wikipedia's rules' - CIPR reacts to accusations of digital vandalism by North Face. Chartered Institute of Public Relations. https://newsroom.cipr.co.uk/respect-wikipedias-rules---cipr-reacts-to-accusationsof-digital-vandalism-by-north-face

Coombs, T. W., \& Holladay, S. J. (2007). It's not just PR: Public relations in society. Blackwell.

Cunningham, P. H. (1999). Ethics of advertising. In J. P. Jones (Ed.), The advertising business: Operations, creativity, media planning, integrated communications (pp. 499-513). Sage. 
DiStaso, M. W. (2013). Perceptions of Wikipedia by public relations professionals: A comparison of 2012 and 2013 surveys. Public Relations Journal, 7(3), 1-23.

DiStaso, M. W., \& Messner, M. (2010). Forced transparency: Corporate image on Wikipedia and what it means for public relations. Public Relations Journal, 4(2), 1-23.

DiStaso, M. W., Messner, M., \& Stacks, D. W. (2012). The wiki crisis: BP's Deepwater Horizon oil spill on Wikipedia. In S. Duhé (Ed.), New media and public relations (2nd ed., pp. 302-310). Peter Lang.

Drumwright, M. E., \& Murphy, P. E. (2004). How advertising practitioners view ethics: moral muteness, moral myopia, and moral imagination. Journal of Advertising, 33(2), 7-24.

Duhé, S. (2015). An overview of new media research in public relations journals from 1981 to 2014. Public Relations Review, 41(2), 153-169.

Enke, N., \& Borchers, N. S. (2019). Social media influencers in strategic communication: A conceptual framework for strategic social media influencer communication. International Journal of Strategic Communication, 13(4), 261-277.

Enke, N., Borchers, N. S., Auksutat, P., Bühler, L., Göbel, S., Maus, S., Prötzsch, M. Schmiech, Y., \& Virgil, F. (2019). Whitepaper Ethikkodex Influencer-Kommunikation. Leipzig University. https://bvim.info/?ddownload=642

Guilbeault, D. (2016). Growing bot security: An ecological view of bot agency. International Journal of Communication, 10, 5003-5021.

Hagelstein, J., \& Zerfass, A. (2020). Dancing with the devil? The adoption of paid media among PR professionals. Paper presented at the Annual Conference of the International Communication Association (ICA). Gold Coast, Australia, May 2020.

Holtzhausen, D. R., \& Zerfass, A. (2015). Strategic communication: Opportunities and challenges of the research area. In D. R. Holtzhausen \& A. Zerfass (Eds.), The Routledge handbook of strategic communication (pp. 3-17). Routledge.

Ikonen, P., Luoma-aho, V., \& Bowen, S. A. (2017). Transparency for sponsored content: Analysing codes of ethics in public relations, marketing, advertising and journalism. International Journal of Strategic Communication, 11(2), 165-178.

Jensen, R. (2011). Blogola, sponsored posts, and the ethics of blogging. In B. E. Drushel \& K. German (Eds.), The ethics of emerging media: Information, social norms, and new media technologies (pp. 213-229). Continuum.

Kent, M. L., \& Taylor, M. (2002). Toward a dialogic theory of public relations. Public Relations Review, 28(1), 21-37.

Lahav, T., \& Roth-Cohen, O. (2016). The changing blogosphere and its impact on public relations practice and professional ethics: The Israeli case. Public Relations Review, 42(5), 929-931.

L'Etang, J. (2011). Public relations and marketing: ethical issues and professional practice in society. In G. Cheney, S. May, \& D. Munshi (Eds.), The handbook of communication ethics (pp. 221-240). Routledge.

Linke, A., \& Kiesenbauer, J. (2015). Teaching ethical principles for PR: An empirical study on university curricula in Germany. In A. Catellani, A. Zerfass \& R. Tench (Eds.), Communication ethics in a connected world: Research in public relations and organisational communication (pp. 263-282). Peter Lang.

Mai, J.-E. (2016). Big data privacy: The datafication of personal information. The Information Society, 32(3), 192-199.

Marten, N., \& Kirchmeer, E. (2018). Mit Leidenschaft anstecken und für den E-Commerce begeistern - Corporate Influencer bei OTTO. In A. Schach \& T. Lommatzsch (Eds.), 
Influencer Relations: Marketing und PR mit digitalen Meinungsführern (pp. 277-284). Springer VS.

Matz, S. C., \& Netzer, O. (2017). Using big data as a window into consumers' psychology. Current Opinion in Behavioral Sciences, 18, 7-12.

Paterson, D., Roads, A., \& Vaught, B. C. (2001). Ethical beliefs of business professionals: A study of gender, age and external factors. Journal of Business Ethics, 31(3), 225-232.

Pearson, R. (1989). A theory of public relations ethics. Unpublished doctoral dissertation. Ohio University.

Phillips, D., \& Young, P. (2009). Online public relations (2nd ed.). Kogan Page CIPR.

Place, K. R. (2019). Moral dilemmas, trials, and gray areas: Exploring on-the-job moral development of public relations professionals. Public Relations Review, 45(1), 24-34.

Post, J. E., Preston, L. E., \& Sachs, S. (2002). Redefining the corporation: Stakeholder management and organizational wealth. Stanford University Press.

PR-Ethik-Rat (2018). Ethics in digital communication. Austrian Ethics Council for Public Relations. http://www.prethikrat.at/wordpress_dev/wp-content/uploads/Code-ofConduct-Digital-Communication_EN_Version-2.0.pdf

Schauster, E., \& Neill, M. (2017). Have the ethics changed? An examination of ethics in advertising and public relations agencies. Journal of Media Ethics, 32(1), 45-60.

Sebastião, S. P., Zulato, G., \& Belo Santos, T. (2017). Public relations practitioners' attitudes towards the ethical use of social media in Portuguese speaking countries. Public Relations Review, 43(3), 537-546.

Sweetser, K. D. (2010). A losing strategy: The impact of nondisclosure in social media on relationships. Journal of Public Relations Research, 22(3), 288-312.

Taiminen, K., Luoma-aho, V., \& Tolvanen, K. (2015). The transparent communicative organization and new hybrid forms of content. Public Relations Review, 41(5), 734743.

Taylor, M. (2010). Public relations in the enactment of civil society. In R. L. Heath (Ed.), The SAGE handbook of public relations (2nd ed., pp. 5-16). Sage.

Toledano, M., \& Avidar, R. (2016). Public relations, ethics, and social media: A cross-national study of PR practitioners. Public Relations Review, 42(1), 161-169.

Toledano, M., \& Wolland, L. F. (2011). Ethics 2.0: Social media implications for professional communicators. Ethical Space: The International Journal of Communication Ethics, 8 (3/4), 43-52.

Transparency International (2019). Corruption perceptions index. https://www.transparency.org/en/cpi/2019/results

Valentini, C. (2015). Is using social media 'good' for the public relations profession? A critical reflection. Public Relations Review, 41(2), 170-177.

Van Reijmersdal, E., Neijens, P., \& Smit, E. (2005). Readers' reactions to mixtures of advertising and editorial content in magazines. Journal of Current Issues and Research in Advertising, 27(2), 39-53.

Verčič, D., \& Tkalac Verčič, A. (2016). The new publicity: From reflexive to reflective mediatisation. Public Relations Review, 42(4), 493-498.

Verčič, D., Tkalac Verčič, A., \& Krishnamurthy, S. (2015). Looking for digital in public relations. Public Relations Review, 41(2), 142-152.

Waters, R. D. (2014). Openness and disclosure in social media efforts: A frank discussion with Fortune 500 and Philanthropy 400 communication leaders. In M. W. DiStaso \& D. S. Bortree (Eds.), Ethical practice of social media in public relations (pp. 3-20). Routledge. 
Wiesenberg, M., \& Tench, R. (2020). Deep strategic mediatization: Organizational leaders' knowledge and usage of social bots in an era of disinformation. International Journal of Information Management, 51, 102042.

Wiesenberg, M., Zerfass, A., \& Moreno, A. (2017). Big data and automation in strategic communication. International Journal of Strategic Communication, 11(2), 95-114.

Wojdynski, B. W., Evans, N. J., \& Hoy, M. G. (2018). Measuring sponsorship transparency in the age of native advertising. The Journal of Consumer Affairs, 52(1), 115-137.

Woolley, S. C., \& Howard, P. N. (2016). Political communication, computational propaganda, and autonomous agents. International Journal of Communication, 10, 4882-4890.

Wright, D. K., \& Hinson, M. D. (2017). Tracking how social and other digital media are being used in public relations practice: A twelve-year study. Public Relations Journal, 11(1). https://prjournal.instituteforpr.org/wp-content/uploads/PRJ-2017-Wright-Hinson-21.pdf.

Yang, K. C. C., \& Kang, Y. (2015). Exploring big data and privacy in strategic communication campaigns: A cross-cultural study of mobile social media users' daily experiences. International Journal of Strategic Communication, 9(2), 87-101.

Zerfass, A. (2008). Corporate communication revisited: Integrating business strategy and strategic communication. In A. Zerfass, B. van Ruler, \& K. Sriramesh (Eds.), Public relations research: European and international perspectives and innovations (pp. 6596). Springer VS.

Zerfass, A., Hagelstein, J., \& Tench, R. (2020). Artificial intelligence in communication management: A cross-national study on adoption and knowledge, impact, challenges and risks. Journal of Communication Management, 24(4), 377-389.

Zerfass, A., Verčič, D., Verhoeven, P., Moreno, A., \& Tench, R. (2012). European Communication Monitor 2012: Challenges and competencies for strategic communication: Results of an empirical survey in 42 countries. EACD/EUPRERA.

Zerfass, A., Verčič, D., \& Wiesenberg, M. (2016). The dawn of a new golden age for media relations? How PR professionals interact with the mass media and use new collaboration practices. Public Relations Review 42(4), 499-508. 